\title{
Analysis of The Philosophy of Life of The People of Lampung as Enrichment in Character Education in History Subjects at SMA Negeri 1 Kibang
}

\section{Achmad Didik Khoirudin, Hermanu, Sariyatun}

Universitas Sebelas Maret

akhoirudin007@gmail.com

\section{Article History}

accepted 1/09/2020

approved 4/10/2020

published $1 / 12 / 2020$

\begin{abstract}
Learning must be a vehicle for the holistic growth and development of students' potentials through their active role towards a better chance. These characters will shape motivation with dignified methods and processes. It turns out that these character values are embodied in the philosophy of life of the people of Lampung. How is the analysis of the philosophy of life of the people of Lampung as enrichment in character education in history subjects at SMA Negeri 1 Kibang? The purpose of this study was to determine the analysis of the philosophy of life of the people of Lampung as enrichment in character education in history subjects at SMA Negeri 1 Kibang for the academic year 2020/2021. This research uses descriptive qualitative research methods with a case study approach. In teaching and learning activities there is an interaction between students regarding the subject matter. After the lesson is completed, the objectives of the analysis of Lampung's philosophical values will be achieved as an enrichment of character education, namely the inculcation of Lampung philosophical values such as Piil pesenggiri, meeting nyimah, nengah nyapur, sakai sambayan, and bejuluk adek. In history lessons, there are also aspects of character that are dominant in history learning, even though all values can be included in each subject, namely eighteen indicators of character education.
\end{abstract}

Keywords: History learning, character education enrichment, Lampung people's philosophical values.

\begin{abstract}
Abstrak
Pembelajaran harus menjadi wahana untuk penumbuh kembangan potensi-potensi siswa secara holistik melalui peran aktif mereka menuju perubahan yang lebih baik. Karakter itu akan membentuk motivasi dengan metode dan proses yang bermartabat. Nilai-nilai karakter ini ternyata sudah terwadahi dalam falsafah hidup yang dimiliki oleh orang Lampung. Bagaimana analisis falsafah hidup orang Lampung Sebagai Pengayaan Dalam Pendidikan Karakter Pada Mata Pelajaran Sejarah di SMA Negeri 1 Kibang?. Tujuan penelitian ini untuk mengetahui Analisis Falsafah Hidup Orang Lampung Sebagai Pengayaan Dalam Pendidikan Karakter Pada Mata Pelajaran Sejarah di SMA Negeri 1 Kibang Tahun Ajaran 2020/2021. Penelitian ini menggunakan metode penelitian kualitatif deskriptif dengan pendekatan studi kasus. Di dalam kegiatan belajar mengajar tersebut terjadi interaksi diantara peserta didik menyangkut materi pelajaran. Setelah pelajaran selesai maka akan dicapai tujuan dari analisis nila-nilai falsafah Lampung sebagai pengayaan pendidikan karakter tersebut yaitu tertanamnya nilai-nilai falsafah Lampung seperti Piil pesenggiri, nemui nyimah, nengah nyapur, sakai sambayan, dan bejuluk adek. Dalam pelajaran sejarah sendiri juga terdapat aspek-aspek karakter yang dominan dalam pembelajaran sejarah walaupun sebenarnya semua nilai bisa dimasukkan di dalam setiap mata pelajaran, yaitu delapan belas indikator pendidikan karakter.
\end{abstract}

Kata Kunci: Pembelajaran sejarah, pengayaan pendidikan karakter, nilai-nilai falsafah orang lampung

Social, Humanities, and Education Studies (SHEs): Conference Series https://jurnal.uns.ac.id/shes

p-ISSN 2620-9284

e-ISSN 2620-9292

This work is licensed under a Creative Commons Attribution-ShareAlike 4.0

International License. 


\section{PENDAHULUAN}

Pendidikan merupakan salah satu sarana terpenting dalam usaha pembangunan sumber daya manusia dan penanaman nilai-nilai kemanusiaan, yang pada gilirannya akan menciptakan suasana dan tatanan kehidupan masyarakat yang beradab dan berperadaban. (Naquib Al-Attas, 2003: 23). Dalam rangka mencerdaskan kehidupan bangsa, maka peningkatan mutu pendidikan suatu hal yang sangat penting bagi pembangunan berkelanjutan di segala aspek kehidupan manusia. Sistem pendidikan nasional senantiasa harus dikembangkan sesuai dengan kebutuhan dan perkembangan yang terjadi baik di tingkat lokal, nasional, maupun global (E. Mulyasa, 2006: 4).

Dewasa ini pendidikan adalah hal yang sangat substansial bagi kehidupan sesorang, sehingga hampir semua orang berbondong-bondong mencari tempat pembelajaran yang favorit, hal ini mengakibatkan sekolah-sekolah atau perguruan tinggi menuntut para pendidiknya bekerja lebih professional. Oleh sebab itu, para pendidik mencari refrensi baru, metode atau model baru, strategi atau bahkan buku-buku baru untuk membuat pembelajaran didalam kelas lebih efektif dan lebih mudah di terima oleh peserta didik, selain membuat pembelajaran efektif pendidik juga membuat pembelajaran bisa membentuk karakter siswa.

Pembelajaran mendapat tempat yang lebih luas, harus menjadi wahana untuk penumbuhkembangan potensi-potensi siswa secara holistik melalui peran aktif mereka menuju perubahan yang lebih baik. Dalam keadaan ini sangat diperlukan upaya-upaya konstruktif guru dalam mengembangkan dimensi-dimensi emosional siswa agar mereka semakin mampu menghadapi berbagai persoalan, bersemangat, ulet, tekun, bertanggung jawab, mampu menjalin komunikasi secara sehat dengan individu atau kelompok lain. Kesemuanya ini merupakan akar-akar emosi yang menjadi landasan untuk mencapai sukses yang diharapkan. (Aunurrahman, 2016:85)

Untuk itu para orang tua siswa atau wali murid sangat setuju dengan peranguru dalam menyisipkan pendidikan nilai, etika, moral dan sopan santun, tentunya orang tua siswa akan merespon positif artinya setuju sepenuhnya. Hal ini dapat dipahami bahwa tingkah laku anak manusia dikendalikan oleh aturan-aturan tertentu (regulated behavior). Dapat dikatakan bahwa peran guru sangatlah penting dalam menentukan sejauh mana sikap siswa dalam bertingkah laku sebagai bagian dari masyarakat, apakah sesuai dengan norma yang berlaku di masyarakat ataukah tidak. Sebagai pendidik atau pengajar, guru merupakan salah satu faktor penentu keberhasilan setiap upaya pendidikan si Sekolah.

Sekolah adalah suatu lembaga yang mempunyai peran strategis dalam mendidik dan menyiapkan sumber daya manusia yang berkualitas dalam memegang estafet generasi sebelumnya (Johnson, 2002: 65). Keberadaan sekolah sebagai sistem tatanan kehidupan sosial, menempatkan lembaga sekolah sebagai bagian dari sistem sosial. Sebagai bagian dari sistem dan lembaga sosial, sekolah harus peka dan tanggap dengan harapan dan tuntutan masyarakat sekitarnya. Sekolah diharapkan menjalankan fungsinya dengan mencerdaskan kehidupan bangsa dengan optimal dan mengamankan diri dari pengaruh negatif lingkungan sekitar (Benninga, 2003: 19; Damon, 2002: 9). Maka dari itu, penelitian ini berusaha untuk menyajikan peran sekolah dalam menciptakan iklim pembelajaran pendidikan karakter kepada siswa.

Salah satu mata pelajaran yang memiliki muatan pendidikan karakter adalah pendidikan Sejarah (Althof, 2006; Aman, 2011: 57; Wineburg, 2001: 6; 495). Mata pelakaran sejarah merupakan pelajaran yang menanamkan pengetahuan, sikap dan nilai-nilai proses mengenai perubahan dan perkembangan masyarakat Indonesia dari dulu hingga sekarang. Nilai-nilai yang terkandung dalam pembelajaran sejarah Indonesia yaitu nilai keilmuan, nilai informatif, nilai etika dan nilai nasioanlisme (Kochar, 2008: 54). Maka jelas bahwa pelajaran sejarah Indonesia tidak hanya menunjang 
pengetahuan siswa melainkan memuat aspek lainnya yang dibutuhkan siswa dalam kehidupan.

Sebagai pengajar dan pendidik guru harus memiliki kompetensi atau kemampuan yang sesuai dalam pembelajaran untuk meningkatkan kualitas pembelajaran. Sugesti perilaku guru begitu besar dimata anak didiknya, bila guru berbuat benar maka murid akan berbuat hal yang sama, bila guru berbuat salah maka anak didik akan berbuat hal yang tidak sekedar salah, tetapi tidak mau disalahkan (Mursidin, 2011:33).

Untuk itu peran guru sejarah tidak hanya menyampaikan materi saja, tetapi harus memberikan pendekatan-pendekatan yang tepat untuk mengembangkan karakter siswa dalam kehidupan sehari-hari baik di lingkungan sekolah, keluarga dan masyarakat sesuai dengan norma dan peraturan yang berlaku di masyarakat.

Pada saat guru mengajar di dalam kelas tentunya perilaku siswa harus di kontrol dengan baik, walaupun terkadang ada siswa yang luput dari kontrol guru, misalnya mereka sering mengobrol saat guru menerangkan materi pembelajaran, atau mereka tidak mendengarkan perkataan dari guru, istilahnya yang sering dikatakan oleh guru adalah "masuk kuping kiri keluar kuping kanan", inilah yang harus dibenahi secara perlahan-lahan.

Sebagai pengajar dan pendidik guru harus memiliki kompetensi atau kemampuan yang sesuai dalam pembelajaran untuk meningkatkan kualitas pembelajaran. Sugesti perilaku guru begitu besar dimata anak didiknya, bila guru berbuat benar maka murid akan berbuat hal yang sama, bila guru berbuat salah maka anak didik akan berbuat hal yang tidak sekedar salah, tetapi tidak mau disalahkan (Mursidin, 2011:33). Untuk itu peran guru tidak hanya menyampaikan materi saja, tetapi harus memberikan pendekatan-pendekatan yang tepat untuk mengembangkan karakter siswa, agar dalam kehidupan sehari-hari baik di lingkungan sekolah, keluarga dan masyarakat sesuai dengan norma dan peraturan yang berlaku di masyarakat.

Menurut Hasan Alwi (2002), Karakter merupakan "Sifat-sifat kejiwaan, akhlak atau budi pekerti yang membedakan seseorang dari yang lain". Sedangkan menurut Coon, karakter sebagai "Suatu penilaian subjektif terhadap kepribadian seseorang yang berkaitan dengan atribut kepribadian yang dapat atau tidak dapat diterima oleh masyarakat" Zubaedi, 2011: 8),. Karakter itu akan membentuk motivasi dengan metode dan proses yang bermartabat. Sementara Nilai-nilai karakter yang diharapkan oleh pemerintah terdapat 18 nilai, antara lain nilai religius, toleransi, jujur, disiplin, kerja keras, kreatif, mandiri, rasa ingin tau, demokratis, cinta tanah air, kebangsaan, menghargai prestasi, bersahabat, cinta damai, gemar membaca, peduli lingkungan, sosial, dan tanggung jawab (Setiawan, 2018: 41). Nilai-nilai karakter ini ternyata sudah terwadahi dalam falsafah hidup yang dimiliki oleh orang Lampung (Amaliah, 2018: 179).

Berdasarkan penelitian yang dilakukan oleh Ariyani (2014: 82) menyebutkan terdapat kata berkarakter dalam penjelasan tentang falsafah hidup yang dimiliki oleh orang Lampung, yaitu (1) Piil Pesenggiri (2) Bejuluk Beadek (3) Nemui Nyimah, (4) Nengah Nyappur, (5) Sakai Sambayan. Dan falsafah hidup orang Lampung ini termaktub didalam kitab Kuntara Raja Niti atau kita hukum adat orang Lampung yang mengatur bagaimana kehidupan orang Lampung kitab ini telah ada sejak zaman Kerajaan Sekala Berak.

Berdasarkan latar belakang yang sudah dijelaskan tersebut peneliti tertarik melakukan penelitian dengan judul Analisis Falsafah Hidup Orang Lampung Sebagai Pengayaan Dalam Pendidikan Karakter Pada Mata Pelajaran Sejarah di SMA Negeri 1 Kibang Tahun Ajaran 2020/2021 . Tujuan penelitian ini adalah untuk menganalisis falsafah diup orang Lampung dalam pengayaan dalam pendidikan karakter pada mata pelajaran sejarah di SMA Negeri 1 Kibang. 


\section{METODE}

Metode penelitian yang digunakan oleh peneliti dalam penelitian ini adalah metode kualitatif. Menurut Creswell (2016) penelitian kualitatif adalah jenis penelitian yang mengeksplorasi dan memahami makna di sejumlah individu atau sekelompok orang yang berasal dari masalah sosial. Penelitian kualitatif secara umum dapat digunakan untuk penelitian tentang kehidupan masyarakat, sejarah, tingkah laku, konsep atau fenomena, masalah sosial, dan lain-lain. Salah satu alasan mengapa menggunakan pendekatan kualitatif adalah pengalaman peneliti dimana metode ini dapat menemukan dan memahami apa yang tersembunyi dibalik fenomena yang kadangkala merupakan suatu yang sulit untuk dipahami. Penelitian ini menggunakan metode penelitian kualitatif deskriptif dengan pendekatan studi kasus. Studi kasus meliputi studi tentang suatu kasus dalam kehidupan nyata, dalam konteks saat ini (Creswell, 2018).

\section{HASIL DAN PEMBAHASAN}

\section{Falsafah hidup orang Lampung}

Menurut Christian Heru Cahyo Saputro (2011;2-4) lampung pepadun menyebut; Piil pesenggiri (prinsip kehormatan), Juluk adek (prinsip keberhasilan), Nemui nyimah (prinsip penghargaan), Nengah nyappur (prinsip persamaan), dan Sakai sambayan (prinsip kerja sama).

a. Dalam pilar pertama, Piil pesenggiri bagi masyarakat Lampung baik bagi penduduk asli maupun pendatang memiliki makna sebagai cara hidup (way of life) ini bermakna setiap gerak dan langkah kehidupan orang Lampung dalam kehidupan sehari-hari dilandasi dengan kebersihan jiwa.

b. Pilar Kedua Nemui Nyimah; terdiri dari dua kata. Kata Nemui yang berarti tamu dan Nyimah yang berasal dari kata Simah yang berarti santun. Orang dikatakan berhasil, jika sanggup menjadi tamu yang baik atau menjadi tuan rumah yang bisa menerima tamu. Apapun posisinya baik sebagai tamu maupun tuan rumah maka yang menjadi ukurannya adalah simah yang berarti santun. Jadi sikap santun menjadi ukuran eksistensi sesorang dalam komunitas masyarakat lampung. Kesantunan seseorang itu bisa dalam bentuk-bentuk prilaku dan tutur kata serta dalam bentuk benda. Jadi seseorang bisa dikatakan santun jika bisa berlaku produktif.

c. Pilar ketiga, Nengah Nyappur; terdiri dari dua kata yaitu kata Nengah dan Nyappur. Kata Nengah memiliki tiga arti yaitu kerja keras, berketerampilan, dan bertanding. Tetapi dalam hal ini haruslah Nyappur yang artinya tenggang rasa. Oleh sebab itu yang dituntut dalam Nengah Nyappur adalah kompetitif. Nengah Nyappur ini juga merupakan salah satu upaya masyarakat lampung untuk membekali diri baik dari sisi intelektual maupun spiritual, sehingga memiliki kemampuan dalam mengorganisir isi alam untuk kemudian dimanfaatkan secara optimal bagi kemakmuran umat manusia.

d. Pilar keempat, Sakai Sambayan; terdiri dari dua kata yaitu Sakai dan Sambayan. Kata sakai berasal dari kata akai yang artinya terbuka dan bisa menerima sesuatu yang datang dari luar. Sedangkan sambayan atau sambai (utusan) yang berarti memberi. Dengan kata lain sakai sambayan adalah sifat kooperatif atau gotong-royong.

e. Pilar kelia, Bejuluk Beadek; berasal dari juluk adek terdiri dari dua kata yaitu juluk adalah nama baru ketika seseorang mampu menancapkan cita-citannya. Sedangkan adek adalah gelar atau nama baru yang diberikan ketika cita-cita itu telah tercapai. Nama-nama baru hanya diberikan ketika ada sesuatu yang baru. Dengan demikian masyarakat lampung selalu menginginkan terjadinya perubahan, pembaharuan dan inovasi. 
Piil pesenggiri, sebagai soko guru filosofi orang lampung dengan keempat pilar penyanggahnya Nemui nyimah, Sakai sambayan, Nengah nyappur, dan Bejuluk beadek sudah sejak berabad-abad hidup dan lalu dijalani oleh masyarakat adat lampung. Piil pesenggiri, etos dan spirit kelampungan ini kalau dijalankan dengan konsisten dan kesungguhan akan mengantarkan manusia pada tatanan kehidupan yang harmonis dan serasi. Piil pesengiri menjauhkan orang dari perpecahan dan makin memperkokoh dalam masyarakat multikultur.

\section{Pengayaan dalam Pendidikan Karakter}

Tujuan pendidikan karakter menurut Mulyasa (2012, hlm.9) adalah untuk mendorong peserta didik agar mampu secara mandiri meningkatkan dan menggunakan pengetahuannya, mengkaji dan menginternalisasikan serta mempersonalisasikan nilai-nilai karakter dan akhlak mulia sehingga terwujud dalam perilaku sehari-hari.

Menurut Thomas Lickona (1992: 12) pendidikan karakter sebagai upaya yang sungguhsungguh untuk membantu seseorang memahami, peduli dan bertindak dengan landasan nilai-nilai etis. Pendidikan karakter menerut Lickona mengandung tiga unsure pokok, yaitu mengetahui kebaikan (knowing the good), mencintai kebaikan (desiring the good), dan melakukan kebaikan (doing the good). Sementara Menurut Saptono (2011: 23) pendidikan karakter adalah upaya yang dilakukan dengan sengaja untuk mengembangkan karakter yang baik (good character) berlandaskan kebaikan-kebaikan inti (core virtues) yang secara objektif baik bagi individu maupun masyarakat.

Kementrian Pendidikan Nasional pada tahun 2010 telah merilis tentang nilainilai Pendidikan Budaya dan Karakter Bangsa. Ada 18 nilai karakter yang harus ditanamkan dalam pendidikan di sekolah dasar. Nilai-nilai karakter itu adalah religius, jujur, toleransi, disiplin, kerja keras, kreatif, mandiri, demokratis, rasa ingin tahu, semangat kebangsaan, cinta tanah air, menghargai prestasi, bersahabat/komunikatif, cinta damai, gemar membaca, peduli lingkungan, peduli sosial, dan tanggung jawab. Untuk mengetahui nilai-nilai karakter maka dilakukanlah penilaian karakter. Penilaian merupakan serangkaian kegiatan yang sistematis dan berkesinambungan untuk memeroleh data dan informasi tentang proses dan hasil belajar peserta didik (Muhammad, 2015:56) Dalam penilaian sikap, diasumsikan setiap peserta didik memiliki karakter dan perilaku yang baik, sehingga jika tidak dijumpai perilaku yang menonjol maka nilai sikap peserta didik tersebut adalah baik, dan sesuai dengan indikator yang diharapkan. Perilaku menonjol (sangat baik/kurang baik) yang dijumpai selama proses pembelajaran dimasukkan ke dalam catatan pendidik. Selanjutnya, untuk menambah informasi, guru kelas mengumpulkan data dari hasil penilaian sikap yang dilakukan oleh guru muatan pelajaran lainnya, kemudian merangkum menjadi deskripsi (bukan angka atau skala).

Penilaian karakter dilakukan secara terus menerus dan dilakukan setiap saat guru berada di kelas atau di sekolah. Model anecdotal record atau catatan anecdotal (catatan yang dibuat guru ketika melihat adanya perilaku yang berkenaan dengan nilai yang dikembangkan) selalu dapat digunakan guru. Selain itu, guru dapat pula memberikan tugas yang berisikan suatu persoalan atau kejadian yang memberikan kesempatan kepada peserta didik untuk menunjukkan nilai yang dimilikinya. Dari hasil pengamatan, catatan anekdotal, tugas, laporan, dan sebagainya, guru dapat memberikan kesimpulan atau pertimbangan tentang pencapaian suatu indikator atau bahkan suatu nilai. Kesimpulan atau pertimbangan itu dapatdinyatakan dalam pernyataan kualitatif Penanaman nilai karakter dapat dilakukan dalam kegiatan pembelajaran.

Kegiatan pembelajaran dilaksanakan agar siswa sekolah dasar mempraktikan nilai-nilai karakter yang ditargetkan teraktualkan melalui kegiatan pendahuluan, 
kegiatan inti dan kegiatan penutup. Pada kegiatan pendahuluan, penanaman nilai karakter dapat dilakukan melalui contoh sebagai berikut:

1. Guru datang tepat waktu (nilai yang ditanamkan: disiplin).

2. Guru mengucapkan salam dengan ramah kepada siswa ketika memasuki ruangan kelas (nilai yang ditanamkan: santun, peduli).

3. Guru berdoa sebelum membuka pelajaran, dan siswa belajar memimpinnya (nilai yang ditanamkan: religius, partisipatif).

4. Guru mengecek kehadiran siswa (nilai yang ditanamkan: disiplin).

5. Guru mendoakan siswa yang tidak hadir atau karena halangan lainnya (nilai yang ditanamkan: religius, peduli).

6. Guru menegur siswa yang terlambat dengan sopan (nilai yang ditanamkan: disiplin, santun, peduli).

7. Guru meminta siswa menghapus papan tulis (nilai yang ditanamkan: peduli, bersih).

8. Guru mengaitkan materi yang akan diajarkan dengan karakter.

9. Guru menyampaikan butir-butir nilai yang akan dicapai dalam pembelajaran. Pada kegiatan inti, penanaman nilai karakter dapat dilakukan melalui kegiatan eksplorasi, elaborasi, dan konfirmasi. Contoh penanaman nilai karakter yang dilakukan pada kegiatan eksplorasi adalah sebagai berikut:

1. Guru melibatkan peserta didik mencari informasi dari tema yang dipelajari berdasarkan aneka sumber belajar (menanamkan: kemandirian, berfikir logis, kreatif dan kerjasama).

2. Guru menggunakan beragam pendekatan pembelajaran yang menantang dan memotivasi (menanamkan: kreatif, kerja keras).

3. Guru memfasilitasi interaksi antar peserta didik serta antara peserta didik dengah guru, lingkungan dan sumber belajar lainnya (menanamkan: saling menghargai dan peduli lingkungan).

4. Guru melibatkan peserta didik secara aktif dalam setiap kegiatan pembelajaran (menanamkan: percaya diri, mandiri).

5. Guru memfasilitasi peserta didik melakukan percobaan (menanamkan: mandiri, kerja keras, teliti).

Kegiatan inti yang kedua adalah kegiatan elaborasi. Contoh penanaman nilai karakter yang dilakukan pada kegiatan elaborasi adalah sebagai berikut:

1. Guru membiasakan membaca dan menulis melalui tugas tertentu (menanamkan: tekun, kreatif, gemar membaca).

2. Guru memfasilitasi diskusi kelas (menanamkan: kreatif, analitis, kritis, saling menghargai, santun).

3. Guru memfasilitasi pembelajaran kooperatif dan kolaboratif (menanamkan: kerjasama, saling menghargai, tanggungjawab).

4. Guru memfasilitasi kompetisi antar warga kelas secara sehat (menanamkan:jujur, menerima keputusan, kerja keras).

5. Guru memfasilitasi pembuatan laporan hasil eksplorasi/kerja secara individual maupun kelompok (menanamkan: mandiri, kerjasama, tanggungjawab, menghargai).

6. Guru memfasilitasi peserta didik menampilkan karya (menanamkan: percaya diri, menghargai karya, jujur, kerjasama).

Kegiatan inti yang ketiga adalah kegiatan konfirmasi. Contoh penanaman nilai karakter yang dilakukan pada kegiatan konfirmasi adalah sebagai berikut:

1. Guru memberikan umpan balik positif (menanamkan: percaya diri, saling menghargai, santun).

2. Guru memfasilitasi peserta didik melakukan refleksi terhadap pengalaman belajar yang telah dilakukan (menanamkan: menerima keadaan, syukur). 
3. Guru memfasilitasi peserta didik menggali pengalaman dan pengetahuan lebih jauh (menanamkan: rasa ingin tahu, tidak cepat puas).

Kegiatan terakhir dalam kegiatan pembelajaran adalah kegiatan penutup. Contoh penanaman nilai karakter yang dilakukan pada kegiatan penutup adalah sebagai berikut:

1. Guru beserta peserta didik membuat rangkuman atau kesimpulan (menanamkan: kritis, logis, kerjasama).

2. Guru melakukan penilaian terhadap kegiatan yang sudah dilaksanakan (menanamkan: jujur, sukur, menerima kelebihan dan kekurangan).

3. Guru memberikan umpan balik terhadap proses dan hasil pembelajaran (menanamkan: saling menghargai, percaya diri, santun, kritis).

4. Guru merencanakan tindak lanjut baik remedi atau pengayaan (menanamkan: tanggung jawab).

5. Guru memfasilitasi siswa untuk berdoa dan berterima kasih (menanamkan: religiousitas, hormat pada guru).

\section{Pelaksanaan dalam pembelajaran Sejarah}

Menurut Malik dalam buku Dirman dan Cicih Juarsih menjelaskan bahwa pembelajaran adalah suatu kombinasi yang tersusun meliputi unsur-unsur manusiawi, material, fasilitas, perlengkapan, dan prosedur yang saling mempengaruhi untuk mencapai tujuan pembelajaran. Manusia yang terlibat dalam sistem pembelajaran terdiri dari peserta didik, guru, dan tenaga lainnya, misalnya tenaga laboratorium. Material, meliputi buku-buku, papan tulis dan kapur, fotografi, slide dan film, audio dan video tape. Fasilitas dan perlengkapan, terdiri dari ruangan kelas, perlengkapan audio visual, juga komputer. Prosedur, meliputi jadwal dan penyampaian informasi, praktik, belajar, ujian, dan sebagainya. Berdasarkan batasan di atas dapat dikatakan bahwa pembelajaran adalah suatu proses kombinatif yang interaktif dari berbagai komponen yang terlibat dalam pembelajaran untuk mencapai tujuan pembelajaran yang telah ditetapkan. Komponen peserta didik dalam proses pembelajaran tersebut adalah subjek belajar yang mempelajari materi atau bahan ajar dengan prosedur, bimbingan dan arahan dari guru yang didukung oleh fasilitas memadai untuk mencapai tujuan pembelajaran yang telah ditetapkan. (Dirman dan Cicih Juarsih, $2014: 40$ ).

Sejarah telah lama menduduki posisi yang penting diantara berbagai mata pelajaran yang diajarkan di berbagai tingkat pendidikan. Oleh Karena itu guru sejarah harus yakin dan tahu benar apa tujuan yang hendak dikejar dan dicapai dalam pembelajarannya. Sedangkan menurut Kochar dalam bukunya Teaching of History menyebutkan sasaran umum pembelajaran sejarah yaitu;

a. mengembangkan pemahaman tentang diri sendiri. Sejarah perlu diajarkan untuk mengembangkan pemahaman tentang diri sendiri. Untuk mengetahui siapa diri kita sendiri diperlukan perspektif sejarah.

b. memberikan gambaran yang tepat tentang konsep waktu, ruang, dan masyarakat. Sejarah perlu diajarkan untuk memperlihatkan kepada anak konsep waktu, ruang dan masyarakat, serta kaitan antara masa sekarang dan masa lampau, antara wilayah lokal dan wilayah lain, antara kehidupan perseorangan dan kehidupan nasional, dan kehidupan dan kebudayaan masyarakat lain dimanapun dalam ruang dan waktu. 
c. membuat masyarakat mampu mengevaluasi nilai-nilai dan hasil yang telah dicapai oleh generasinya. Sejarah adalah ilmuyang unik karena posisinya yang sangat strategis dalam menyediakan standar-standar bagi generasi muda untuk mengukur nilai dan kesuksesan yang telah dicapai pada masa mereka. sejarah membuat mereka peka terhadap berbagai permasalahan masyarakat, politik, sosial, dan ekonomi pada dewasa ini.

d. mengajarkan toleransi. Sejarah diajarkan untuk mendidik para siswa agar memiliki toleransi terhadap perbedaan keyakinan, kesetiaan, kebudayaan, gagasan, dan cita-cita.

e. menanamkan sikap intelektual. Pembelajaran sejarah dapat melatih siswa agar akurat saat menyusun pemahaman yang komprehensip serta menuliskannya, mempertimbangkan buktibukti, memisahkan hal-hal sepele dari yang penting dan membedakan antara propaganda dan kebenaran.

f. memperluas cakrawala intelektualitas. Sejarah diajarkan untuk memperluas cakrawala intelektualitas para siswa.

g. mengajarkan prinsip-prinsip moral. Pengetahuan sejarah merupakan pengetahuan praktis, merupakan pembelajaran filsafat, merupakan penglihatan yang berasal dari pengalaman. Sejarah memaparkan perbuatan yang buruk, membuka kedok kebaikan yang palsu, menunjukkan kesalahan dan prasangka.

h. menanamkan orientasi kemasa depan. Sejarah diajarkan untuk mendorong siswa agar memiliki visi kehidupan kedepan dan bagaimana cara mencapainya.

i. memberikan pelatihan moral. Sejarah dapat merangsang pikiran, penilaian, dan pemilahan, serta menciptakan sikap ilmiah pada orang dewasa sebagai imbangan terhadap ketidakstabilan emosinya.

j. melatih siswa menangani isu-isu kontrovesial. Pembelajaran sejarah sangat penting untuk melatih para siswa menangani permasalahan yang kontrovesial dengan berlandaskan semangat mencari kebenaran sejati melalui diskusi, debat dan kompromi.

k. membantu mencarikan jalan keluar bagi berbagai masalah sosial dan perseorangan. Pembelajaran sejarah membantu masyarakat menemukanjalan keluar dari berbagai permasalahan yang dewasa ini sedang dihadapi.

I. memperkokoh rasa nasionalisme. Sasaran khusus pembelajaran sejarah adalah menumbuhkan semangat siswa untuk terus menerus menghidupkan prinsip keadilan dan kemanusiaan sebagai pilar kehidupan bangsa. Sejarah menjadi jalan untuk menanamkan semangat patriotisme.

m. mengembangkan pemahaman internasional. Sejarah perlu diajarkan untuk mengembangkan pemahaman tentang bangsa lain di dunia pada siswa.

n. mengembangkan keterampilan-keterampilan yang berguna antara lain; keterampilan menggunakan, mengartikan, dan menyiapkan media pembelajaran; keterampilan membaca; keterampilan berdiskusi tentang isu-isu kontivesial. (Kochhar, 2008 : 27-37).

Nilai-nilai Falsafah Lampung disini bukan sebagai mata pelajaran yang berdiri sendiri, tapi disini sebagai konseptual yang diigunakan kedalam perangkat pembelajaran seperti RPP, silabus, modul pembelajaran dan evaluasi pembelajaran yang akan dilaksanakan pada proses pembelajaran sejarah yang sedang berlangsung. Di dalam kegiatan belajar mengajar tersebut terjadi interaksi diantara peserta didik menyangkut materi pelajaran. Setelah pelajaran selesai maka akan dicapai tujuan dari analisis nila-nilai falsafah Lampung sebagai pengayaan pendidikan karakter tersebut yaitu tertanamnya nilai-nilai falsafah Lampung seperti Piil pesenggiri, nemui nyimah, nengah nyapur, sakai sambayan, dan bejuluk adek. 
Dalam pelajaran sejarah sendiri terdapat aspek-aspek karakter yang dominan dalam pembelajaran sejarah walaupun sebenarnya semua nilai bisa dimasukkan di dalam setiap mata pelajaran, diantaranya nilai religius, jujur, toleransi, disiplin, kerja keras, kreatif, mandiri, demokratis, rasa ingin tahu, semangat kebangsaan, cinta tanah air, menghargai prestasi, bersahabat/komunikatif, cinta damai, gemar membaca, peduli lingkungan, peduli sosial, dan tanggung jawab.

\section{SIMPULAN}

Berdasarkan hasil penelitian yang telah dianalisa, maka peneliti menyimpulkan sebagai berikut:

1. Analisis Nilai-nilai Falsafah hidup orang Lampung yang tanamkan dalam pembelajaran sejarah sebagai pengayaan pendidikan karakter diantaranya piil pesinggiri, nemui nyimah, nengah nyapur, sakai sambayan, dan bejuluk adek.

2. Analisis Nilai-nilai Falsafah hidup orang Lampung tersebut mengandung pendidikan karakter khususnya bagi masyarakat Lampung yang sejalan dengan pendidikan karakter yang disampaikan oleh Kemendikbud, religius, jujur, toleransi, disiplin, kerja keras, kreatif, mandiri, demokratis, rasa ingin tahu, semangat kebangsaan, cinta tanah air, menghargai prestasi, bersahabat/komunikatif, cinta damai, gemar membaca, peduli lingkungan, peduli sosial, dan tanggung jawab.

3. Analisis Nilai-nilai Falsafah hidup orang Lampung dalam pembelajaran sejarah pelaksanaannya sejak tahap perencanaan pembelajaran menyesuaikan kurikulum yang ada dalam pelajaran sejarah, sedang pada tahap pelaksanaan pembelajaran terdukung pula oleh media dan metode pembelajaran yang sesuai dan dipahami bersama oleh guru dan peserta didik.

\section{DAFTAR PUSTAKA}

Al-Attas, Muhammad Naquib. 2003. Konsep Pendidikan Islam, Suatu Rangka fakir Pembinaan filsafat Pendidikan Islam. Terj. Haidar Bagir. Jakarta: Mizan.

Althof, W \& Berkowitz, M. W. (2006). Moral Education and Character Education: Their Relationship and Roles in Citizenship Education. Journal of Moral Education, 35 (4), 495-518.

Amaliah, D., Sariyatun, \& Musaddad. (2018). Value of Piil Pesenggiri: Morality, Religiosity, Solidarity and Tolerance. International Journal of Multicultural and Multireligioes Understanding, 5 (1), 179-184.

Aman. (2011). Model Evaluasi Pembelajaran Sejarah. Yogyakarta: Ombak.

Aunurrahman. (2016). Belajar dan Pembelajaran. Bandung: Alfabeta.

Ariyani, F. (2014). Konsepsi Piil Pesenggiri Menurut Masyarakat Adat Lampung Waykanan di Kabupaten Waykanan. Bandar Lampung: Aura.

Benninga, J.S (2003). The Relationship of Character Education Implementation and Academic Achievement in Elementary School. Journal of Research in Character Education, 1(1), 19-32.

Creswell, J. (2016). Riset Pendidikan: Perencanaan, Pelaksanaan, dan Evaluasi Riset Kualitatif dan Kuantitatif Edisi Kelima, terjemahan Helly Prajitno Soetjipto dan Sri Mulyantini Soetjipto, Yogyakarta: Pustaka Pelajar. 
Cristian Heru C.S. 2011. Piil Pesenggiri Etos dan Semangat Kelampungan. Lampung:Jung Foundation Lampung Heritage

Dirman dan Cicih Juarsih. (2014). Teori Belajar dan Prinsip-prinsp Pembelajaran yang mendidik. Jakarta: PT. Rineka Cipta

E. Mulyasa. 2006. Kurikulum yang di sempurnakan. Bandung: PT Remaja Rosdakarya. Johnson, Elaine B. 2002. Contextual Teaching and Learning. California: Corwin Press.

Kochar, S.K. (2008). Pembelajaran Sejarah. Jakarta: PT Grasindo.

Lickona, Thomas. (1992). Educating for Character, Mendidik untuk Membentuk Karakter. Jakarta: Bumi Aksara.

Mulyasa. 2012. Praktek Penelitian Tindakan Kelas. 2012. Bandung: PT Remaja Rosdakarya.

Mursidin. (2011). Moral Sumber Pendidikan. Bogor: Ghalia Indonesia.

Saptono. 2011. Dimensi-dimensi Pendidikan Karakter Wawasan, Strategi, dan Langkah Praktis. Jakarta: Erlangga.

Wineburg, S. (2001). Historical Thinking and Other Unnatural Acts: Charting the Future of Teaching the Past. Philadelphia: Temple University Press halam 6

Zubaedi. 2011. Desain Pendidikan Karakter, Konsepsi dan Aplikasinya dalam Lembaga Pendidikan. Jakarta: Kencana Prenada Media Group 